\title{
UGV for Close Support Dismounted Operations - Current Possibility to Fulfil Military Demand
}

\author{
Marian J. LOPATKA ${ }^{1}$ \\ ${ }^{1}$ Institute of Robots and Machinery Construction, Faculty of Mechanical Engineering, Military University of \\ Technology, Kaliskiego Str. 2, 00-908 Warsaw, Poland \\ E-mail: ${ }^{1}$ marian.lopatka@wat.edu.pl
}

\begin{abstract}
The problem of dismounted operation support with Unmanned Ground Vehicles (UGV) often called robots is widely discussed and many solutions were tested to verify theory and find technological gaps and limitation for such application. In this paper the initial demand and requirements and their evolution is described on an example of US Army. Described changes concerns demanded level of autonomy, fire support possibility, possibility of performing combat engineer tasks, using UGV for reconnaissance, surveillance, and target acquisition, longitudinal and lateral stability, obstacle negotiation and overall terrain mobility and efficiency of make use of the "mule".
\end{abstract}

KEY WORDS: unmanned ground vehicle, dismounted operation support, mule function, requirements, trials

\section{Introduction}

Unmanned Ground Vehicles (UGV) have been developed for over 20 years in different size, weight, payload and applications. The most popular classes are:

- throwable UGV - weight up to $2 \mathrm{~kg}$, with very limited payload;

- backpackable UGV - weight up to $25 \mathrm{~kg}$ (can be carry by $1 \mathrm{man}$ ), with payload up to 5-10 kg;

- portable UGV - weight up to $75 \mathrm{~kg}$ (can be transported in any military vehicle and loaded/reloaded by 2 man), with payload up to $30 \mathrm{~kg}$;

- $\quad$ light UGV - weight up to about $300 \mathrm{~kg}$ (can be transported in adapted military vehicle), with payload $150-200 \mathrm{~kg}$;

- medium UGV - weight up to about $1000 \mathrm{~kg}$ (can be transported on the trailer or in adapted military vehicle), with payload $300-500 \mathrm{~kg}$;

- heavy UGV - weight up to about $5000 \mathrm{~kg}$ (can be transported on the trailer or towed), with payload up to $2000 \mathrm{~kg}$;

- very heavy UGV - weight above $5000 \mathrm{~kg}$ (can be transported on the trailer or towed) are typically robotized version of military maned vehicles.

- Their main field of applications covers:

- UGV cooperation with maned vehicle teams in combat missions;

- $\quad$ supporting dismounted missions;

- $\quad$ conducting EOD (Explosive Ordnance Disposal) and IED (Improvised Explosive Device) missions.

Efficiency of UGV operation strongly depends on complexity of tasks, needed velocity of operation and demanded autonomous level of operation. The highest requirements are arising from co-action with manned combat vehicle - there are problems with communication and latency on long distances, navigation and path planning, and above all possibility of autonomous action and decision making. To solve the problems the progress in artificial intelligence is needed. On opposite side one may find EOD/IED missions. Relatively short distance of operation, lower time pressure, low pressure for autonomy and high level of threats for soldiers triggered introduction to army in short times a few types of UGV equipped with arms and other attachments. Now all modern army are using EOD/IED robots. UGV for supporting dismounted missions are not in service. The possibility of using them are strongly depend on planned tasks and level of demand and requirements.

${ }^{1}$ Corresponding author. Tel.: +48 261-83-96-16.

E-mail address: marian.lopatka@wat.edu.pl 


\section{Tasks and Requirements}

The necessity to conduct of dismounted operation possess a few reasons and is caused mainly by:

- terrain - not accessible for vehicles (narrow path in jungle or mountain or in urban area, hilly slops, rocks and stones, soft and wet surface with low capacity);

- stealth of action - preparation and movement during operation with using standard size military vehicles is hard to hide and relatively easy to detect;

- requirements for limitation volume and mass of equipment used for operation (logistic background).

Special attention should be taken on reducing the burden on the dismounted soldier. Current soldier load for 3 day mission cover [1]:

- clothing, PLCE \& FP

- weapons equipment

$22.3 \mathrm{~kg}$;

- ammunition

$2.9 \mathrm{~kg}$;

communication equipment $\quad 5.4 \mathrm{~kg}$

- personal equipment $7.3 \mathrm{~kg}$;

- rations and water $8.2 \mathrm{~kg}$

Total weight of gear $74.2 \mathrm{~kg}$ limits mobility, agility and survivability of soldier. In such condition, crucial for task force is reduction the burden on dismounted soldier by using UGV - robotic support vehicle. Ability to effective fulfil all demanded task in wide spectrum of terrain require extreme mobility:

- to climb over walls and cliffs;

- to cross gaps, fences, stairs, curbs, logs, debris, trenches and drainage ditches, rivers, vegetation (thick forest, scrubs, plants) mine field;

- to go through doors, hole in walls, tunnels;

- to move on all surfaces - road, rubble, stones, sand, snow, swamp and slopes.

The first description of requirements for dismounted missions support system was described in US Army Future Combat System (FCS) program (2003 - 2009) [2,3]. Support tasks generally should cover:

- combat support - involving reconnaissance, surveillance, target acquisition and fire support;

- combat engineer support - involving mine detection, path clearance, obstacle breaching, light bridge erection and field fortification;

- logistic support (MULE) - involving transport of munitions and team weapons, combat engineer means, means of signal, spare battery and battery charging, water, food and medevac.

The possibility to fulfil such wide spread of tasks should be achieved with the same base UGV by modularity - exchange modules of special set of payloads. According to the purpose, the mobility of UGV should be extreme - better than conventional vehicle, a specially in obstacle negotiation. It could climb at least a 1-meter step, traverse side slopes greater than 40 percent, ford water to depths over 0.5 meters and overpass obstacles as high as 0.5 meters, while compensating for varying payload weights and center of gravity locations, to safely follow dismounted troops over rough terrain, through rock and debris fields, and over urban rubble. Moreover, UGV needs have active suspension, quiet drive and high level of autonomy.

Worked out wheeled 6x6 demonstrator of Multifunction Utility/Logistics and Equipment vehicle (MULE) weight about $2300 \mathrm{~kg}$ and payload up to $1090 \mathrm{~kg}$ with hybrid drive $(2.1 \mathrm{~m}$ width and about $5 \mathrm{~m}$ length $)$ was able carry two squads' worth of weapons, ammo and equipment, cross 1.5 -meter gaps, traverse side slopes greater than 40 percent, ford water to depths over 1.25 meters, and overpass obstacles as high as 0.5 meter while compensating for varying payload weights and center of gravity locations.

Conducted trials and tests show that testbed is to big and to heavy to accompany and support dismounted soldiers. Moreover independent, active controlled, articulated suspension was to complex and need to much attention and ability to autonomous operation is not possible in short time.

FCS program was terminated in 2009 but on this basis, the new SMET (Squad Multipurpose Equipment Transport) program was started and requirements were amended [4]. SMET was designed for support only one dismounted maneuver squad in IBCT. The payload was lowered to $454 \mathrm{~kg}(1000 \mathrm{lbs})$ and development was based on tests and evaluation of available UGVs and systems using soldier-led evaluation. Overall demands were similar to previous program - the UGV should autonomously navigate in terrain, to have "follow-me" function and high level of mobility. The SMET:

- should be capable of carrying the equipment currently required by a nine-man squad for a 96 hours operation;

- should have the capability to recharge the squad's radio and other batteries to support required operations;

- should be capable of operating in three control regimes: tele-operation, semi-autonomous and autonomous.

- semi-autonomous navigation will include wireless leader/ follower and waypoint navigation. 
- $\quad$ the speed of the SMET will allow for the squad to maintain its momentum during all operations.

The SMET should support mobility requirements across the range of mobility operations and should accommodate several mission payloads, conduct casualty evacuation, mine routes clearance operations, transport ammunition, barrier materials for obstacles and food and water supplies for dismounted mortar platoons. Should serving as a mobile communications platform, towed artillery ammunition carrier, robotic weapon system and network retransmission platform, also should generate power that can be exported and used for charging batteries or powering other systems. The proposed SMET vehicle needs to traverse forward and backward on slopes of up to 30 percent and descending on slopes of 60 percent. Similar requirements were worked out in British MOD in program Personal Robotic Support Vehicle and Assisted Carriage program [1].

Table 1.

UGV tested in SMET program

\begin{tabular}{|c|c|c|c|c|c|c|}
\hline UGV - vendor & $\begin{array}{l}\text { Undercarriage, } \\
\text { suspension }\end{array}$ & $\begin{array}{l}\text { Steering and } \\
\text { drive system }\end{array}$ & $\begin{array}{l}\text { Speed, } \\
\mathrm{km} / \mathrm{h}\end{array}$ & $\begin{array}{l}\text { Width, m } \\
\text { Length, m }\end{array}$ & $\begin{array}{l}\text { Payload, kg } \\
\text { Weight, kg }\end{array}$ & Range \\
\hline $\begin{array}{l}\text { CaMEL - Northrop } \\
\text { Grumman Corp. }\end{array}$ & $\begin{array}{l}\text { Wheeled 6x6/ } \\
\text { tracks, rigid }\end{array}$ & $\begin{array}{l}\text { Pivot steer } \\
\text { Hybrid }\end{array}$ & 8 & $\begin{array}{l}0,81 \\
1.83\end{array}$ & $\begin{array}{c}350 \\
-\end{array}$ & $20 \mathrm{~h}$ \\
\hline $\begin{array}{l}\text { MUTT/J5 - General } \\
\text { Dynamic Land System }\end{array}$ & $\begin{array}{l}\text { Wheeled } 4 \times 4 \\
\text { flexible }\end{array}$ & $\begin{array}{l}\text { Pivot steer } \\
\text { Electric }\end{array}$ & 8 & $\begin{array}{l}1.42 \\
2.13\end{array}$ & $\begin{array}{r}275 \\
\sim 340\end{array}$ & $22 \mathrm{~km}$ \\
\hline $\begin{array}{l}\text { MUTT/J5T - General } \\
\text { Dynamic Land System }\end{array}$ & $\begin{array}{l}\text { Tracked } 4 x 4 \\
\text { flexible }\end{array}$ & $\begin{array}{l}\text { Pivot steer } \\
\text { Electric }\end{array}$ & 8 & $\begin{array}{l}1.52 \\
2.13\end{array}$ & $\begin{array}{r}275 \\
\sim 480\end{array}$ & $22 \mathrm{~km}$ \\
\hline $\begin{array}{l}\text { Protector with trailer - } \\
\text { HDT Global }\end{array}$ & $\begin{array}{l}\text { Metal tracks } \\
\text { Independent }\end{array}$ & $\begin{array}{l}\text { Pivot steer } \\
\text { Hydraulic }\end{array}$ & 8 & $\begin{array}{l}0,91 \\
1.96\end{array}$ & $\begin{array}{l}227+227 \\
590+227\end{array}$ & $100 \mathrm{~km}$ \\
\hline $\begin{array}{l}\text { RS-1 - Howe and } \\
\text { Howe }\end{array}$ & $\begin{array}{l}\text { Rubber track } \\
\text { flexible }\end{array}$ & $\begin{array}{l}\text { Pivot steer } \\
\text { Hydraulic }\end{array}$ & 16 & $\begin{array}{l}0.91 \\
1.85\end{array}$ & $\begin{array}{l}454 \\
680\end{array}$ & $10 \mathrm{~h}$ \\
\hline $\begin{array}{l}\text { RV-M - Polaris } \\
\text { Industries Inc }\end{array}$ & $\begin{array}{l}\text { Rubber tracks } \\
\text { Independent }\end{array}$ & $\begin{array}{l}\text { Pivot steer } \\
\text { Hybrid }\end{array}$ & 24 & $\begin{array}{l}1.09 \\
1.73\end{array}$ & $\begin{array}{l}135 \\
720\end{array}$ & $20 \mathrm{~h}$ \\
\hline $\begin{array}{l}\text { SMSS - Lockheed } \\
\text { Martin }\end{array}$ & $\begin{array}{l}\text { Wheeled } 6 \times 6 \\
\text { rigid }\end{array}$ & $\begin{array}{l}\text { Pivot steer } \\
\text { Hydraulic }\end{array}$ & 24 & $\begin{array}{l}1.80 \\
3.68\end{array}$ & $\begin{array}{c}540 \\
1700\end{array}$ & $200 \mathrm{~km}$ \\
\hline $\begin{array}{l}\text { AMBOT - American } \\
\text { Robot Company }\end{array}$ & $\begin{array}{l}\text { Wheeled } 4 \times 4 \\
\text { flexible }\end{array}$ & $\begin{array}{l}\text { All wheel steer } \\
\text { Electric }\end{array}$ & 19 & $\begin{array}{l}1.07 \\
1.27\end{array}$ & $\begin{array}{r}250 \\
\sim 300\end{array}$ & $8 \mathrm{~h}$ \\
\hline $\begin{array}{l}\text { PROBOT - Roboteam } \\
\text { NA Inc. }\end{array}$ & $\begin{array}{l}\text { Wheeled } 4 \times 4 \\
\text { rigid }\end{array}$ & $\begin{array}{l}\text { Pivot steer } \\
\text { Electric }\end{array}$ & 9,6 & $\begin{array}{l}1,27 \\
1,46\end{array}$ & $\begin{array}{l}700 \\
410\end{array}$ & $8 \mathrm{~h}$ \\
\hline $\begin{array}{l}\text { TITAN - QinetiQ NA / } \\
\text { Milrem }\end{array}$ & $\begin{array}{l}\text { Tracked } \\
\text { rigid }\end{array}$ & $\begin{array}{l}\text { Pivot steer } \\
\text { Hybrid }\end{array}$ & 40 & $\begin{array}{l}2,00 \\
2,40\end{array}$ & $\begin{array}{c}750 \\
1450\end{array}$ & $8-10 \mathrm{~h}$ \\
\hline $\begin{array}{l}\text { Grizzly - Howe and } \\
\text { Howe }\end{array}$ & $\begin{array}{l}\text { Rubber tracks } \\
\text { flexible }\end{array}$ & $\begin{array}{l}\text { Pivot steer } \\
\text { Hybrid }\end{array}$ & & $\begin{array}{l}\sim 1,5 \\
\sim 2.4\end{array}$ & $\begin{array}{c}454 \\
-\end{array}$ & $100 \mathrm{~km}$ \\
\hline $\begin{array}{l}\text { Hunter WOLF - HDT } \\
\text { Global }\end{array}$ & $\begin{array}{l}6 \times 6 \text { Tweel } \\
\text { rigid }\end{array}$ & $\begin{array}{l}\text { Pivot steer } \\
\text { Hybrid }\end{array}$ & 32 & $\begin{array}{l}1,40 \\
2,30\end{array}$ & $\begin{array}{c}454 \\
1100\end{array}$ & $100 \mathrm{~km}$ \\
\hline $\begin{array}{l}\text { MUTT 8x8 - General } \\
\text { Dynamic Land System }\end{array}$ & $\begin{array}{l}\text { wheeled } 8 \times 8 \\
\text { rigid }\end{array}$ & $\begin{array}{l}\text { Pivot steer } \\
\text { Hybrid }\end{array}$ & & $\begin{array}{l}1,78 \\
2,95\end{array}$ & $\begin{aligned} & 545 \\
\sim & 1100\end{aligned}$ & $100 \mathrm{~km}$ \\
\hline $\begin{array}{l}\text { MRZR-X - Team } \\
\text { Polaris }\end{array}$ & $\begin{array}{c}4 \times 4 \times 2 \\
\text { independent }\end{array}$ & $\begin{array}{l}\text { Ackerman } \\
\text { Hybrid }\end{array}$ & 100 & $\begin{array}{l}1,52 \\
3,60\end{array}$ & $\begin{array}{c}454 \\
1600\end{array}$ & $100 \mathrm{~km}$ \\
\hline
\end{tabular}

\section{Demand Evaluation}

The SMET program deploys wide spectrum of robotic systems developed in previous programs, for SMET program and other like the Project Workhorse unmanned ground vehicle (UGV) competition sponsored by the Army. For example, were tested (tab.1):

- CaMEL (Carry-all Modular Equipment Landrover - Northrop Grumman) - fig.1 - narrow UGV (0.81 m) with hybrid drive developed speed $8 \mathrm{~km} / \mathrm{h}$, and with wheeled $6 \times 6$ gear with rigid suspension and with 
removable tracks and pivot steer;

- Protector (HDT Global) - fig.2 - narrow UGV $(0.91 \mathrm{~m})$ with hydraulic drive developed speed $8 \mathrm{~km} / \mathrm{h}$, and with metal track gear and independent suspension and pivot steer;

- $\quad$ RS-1 (Howe and Howe) - fig.3 - narrow UGV (0.91 m) with hydraulic drive developed speed $16 \mathrm{~km} / \mathrm{h}$, and with rubber track gear and flexible suspension and pivot steer;

- AMBOT (American Robot Company) narrow UGV (1 m) with electric drive developed speed $19 \mathrm{~km} / \mathrm{h}$, and with wheeled 4x4 gear and flexible suspension and all independent wheel steer;

- $\quad$ SMSS (Squad Mission Support System - Lockheed Martin) - fig.4 - wide UGV (1.8 m) with hydraulic drive developed speed $24 \mathrm{~km} / \mathrm{h}$, and with wheeled $6 \times 6$ gear and rigid suspension and pivot steer;

- MUTT/Argo J5 (Multi-Utility Tactical Transport - General Dynamic Land System) - fig.5 - relatively wide UGV $(1.4 \mathrm{~m})$ with electric drive developed speed $8 \mathrm{~km} / \mathrm{h}$, and with wheeled $4 \times 4$ gear and flexible suspension and pivot steer;

- MUTT/Argo J5T (Multi-Utility Tactical Transport - General Dynamic Land System) - fig.6 - relatively wide UGV $(1.5 \mathrm{~m})$ with electric drive developed speed $8 \mathrm{~km} / \mathrm{h}$, and with 4 rubber track gear and flexible suspension and pivot steer;

- $\quad$ MUTT/8x8 (Multi-Utility Tactical Transport - General Dynamic Land System) - fig.7 - wide UGV (1.8 $\mathrm{m}$ ) with hybrid drive developed speed $30 \mathrm{~km} / \mathrm{h}$, and with wheeled $8 \times 8$ gear and rigid suspension and pivot steer;

- MRZR-X (Team Polaris) -fig.8 - relatively wide UGV (1.5 m) with hybrid drive developed speed 100 $\mathrm{km} / \mathrm{h}$, and with wheeled $4 \mathrm{x} 4$ gear and independent suspension and Ackerman steering system;

- Hunter WOLF (HDT Global) - fig.9 - relatively wide UGV (1.4 m) with hybrid drive developed speed $32 \mathrm{~km} / \mathrm{h}$, and with wheeled (Tweel) 6x6 gear and rigid suspension and pivot steer;

- Grizzly - (Howe and Howe) fig.10 - wide UGV $(1.8 \mathrm{~m})$ with hybrid drive, with rubber tracked undercarriage, flexible suspension and pivot steer.

Moreover, foreign UGVs like Titan (Qinetiq NA - Milrem) or Probot (Roboteam NA Inc) were also tested. All this UGV were used for evaluation on the SMET range to help the army in developing requirements in operational range, speed, load-bearing capacity, navigation options, including tethered, wireless and autonomous, mobility and maneuverability in multiple terrain, obstacle detection and avoidance, energy efficiency categories.

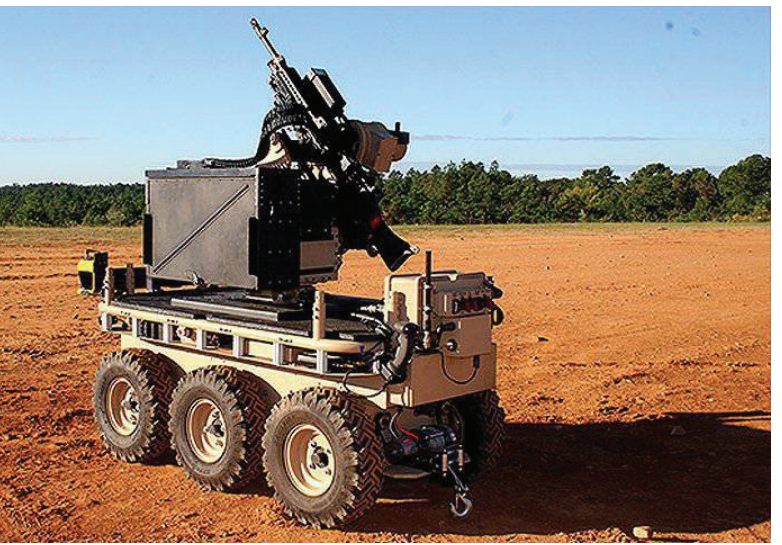

Fig.1. UGV CaMEL [18].

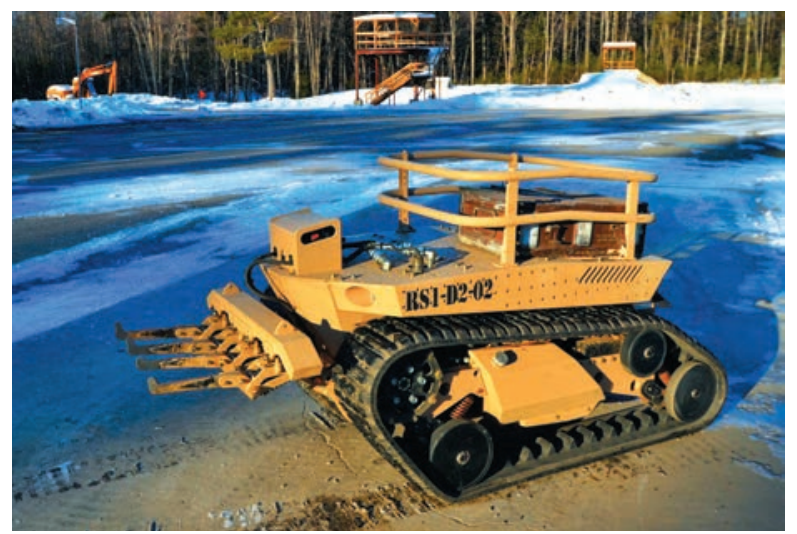

Fig.3. UGV RS - 1 [20].

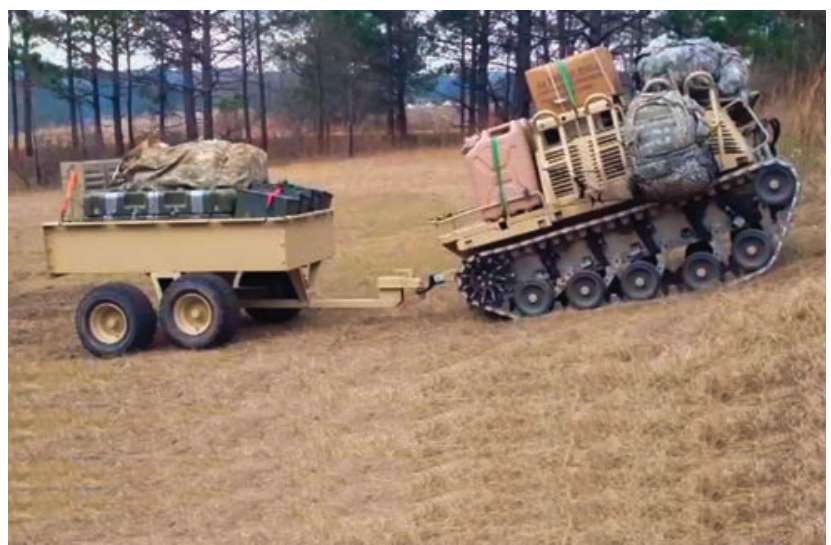

Fig. 2. UGV Protector [19].

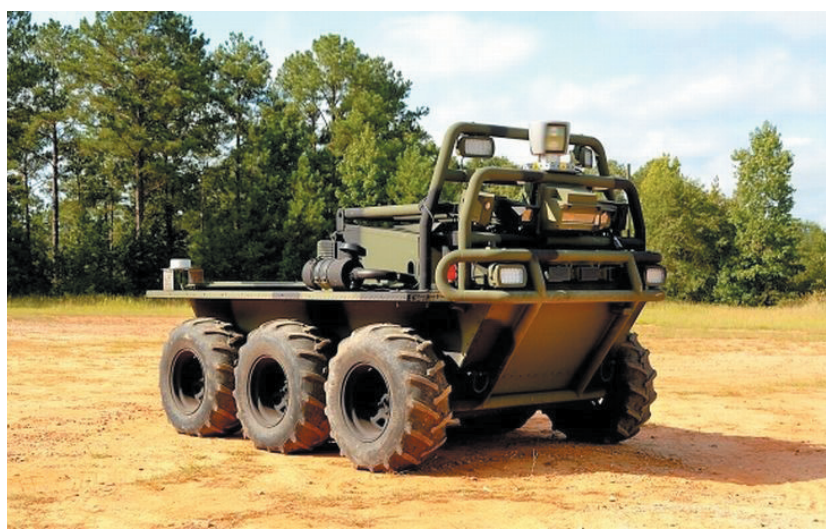

Fig.4. UGV SMSS [21] 


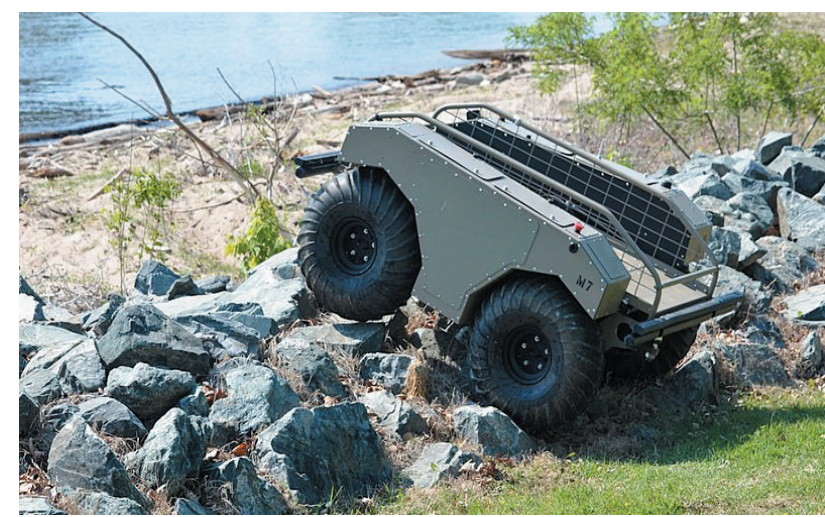

Fig.5. UGV MUTT/J5 [22].

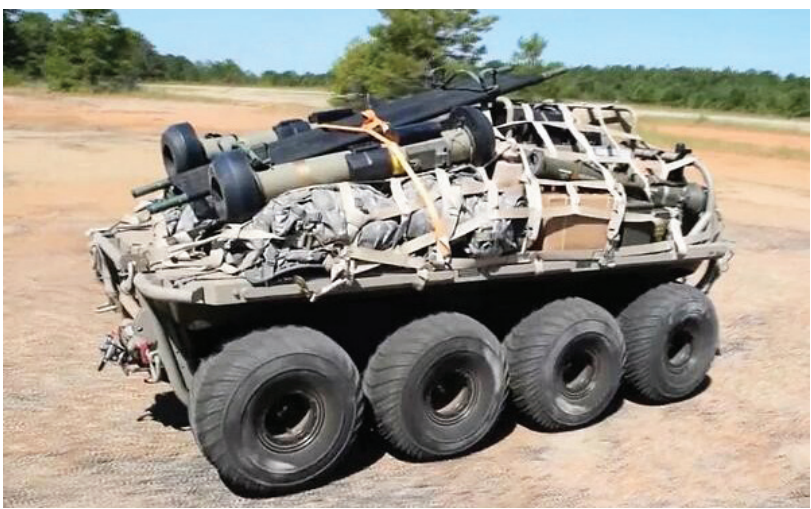

Fig.7. UGV MUTT/8x8 [24].

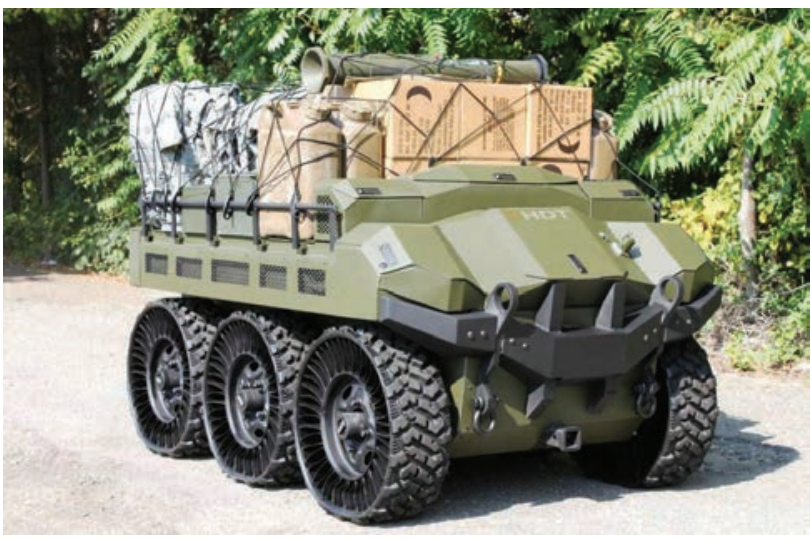

Fig.9. UGV Hunter WOLF [26].

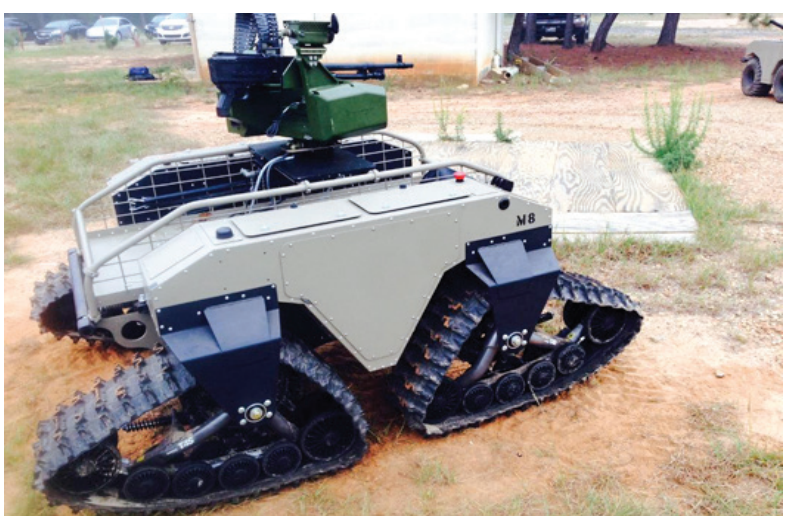

Fig.6. UGV MUTT/J5T [23].

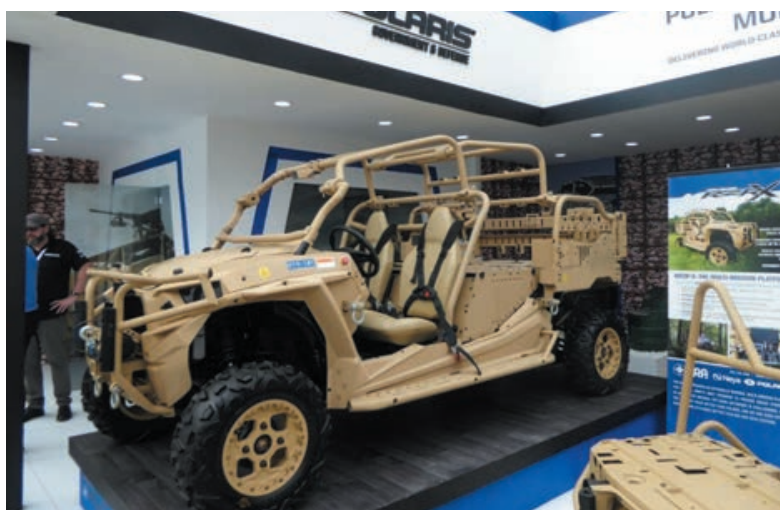

Fig.8. UGV MRZR-X [25].

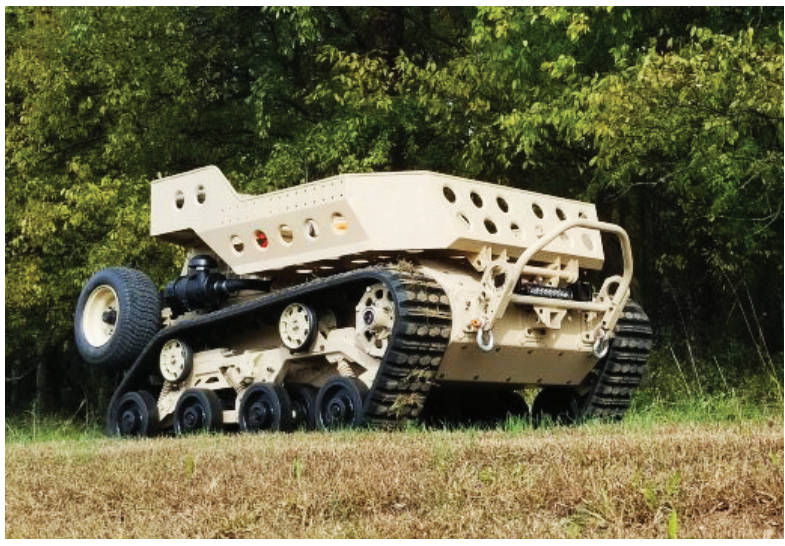

Fig.10. Grizzly [27].

For exploring technological gaps and developing SMET requirements and demands, a lot of tests and trials were made. For example, three-month military utility assessment (MUA) was made in 2011. Four Squad Mission Support System (SMSS) vehicles were deployed to Afghanistan [5]. They were used to resupply small combat outposts and strongpoints two kilometers away, and construction projects on its larger forward operating base. Moving in rough terrain was a challenge for the SMSS vehicles; they could not discern between soldiers and obstacles like trees, so they mostly traveled on roads instead of complex terrain.

Another complex trials were conducted during the U.S. Army Maneuver Center of Excellence Robotics Limited Demonstration Oct. 7-10 at Fort Benning, Ga. 2013 [6]. The program objective was to find an unmanned robotic platform to transport soldier's equipment and charge batteries for their electronic gear. Other autonomous functions, such as follow-me, go-to-point and retro-traverse, were also demonstrated and tested. They found that UGVs with rigid wheeled gear (SMSS) are not too good in obstacle negotiation and not working well in rough terrain.

More complex trials take place during Network Integration Evaluation (NIE) 16.1, which was a two-month long exercise with an infantry company and combat engineer squad [7,8]. The exercise used over ten different SMET surrogate vehicles like Protector, MUTT/J5T, RS-1, RV-M, that were provided by several different vendors.

The assumption for exercise was as follows. A dismounted rifle company with supplies for 72 hours of operations must rapidly move to the objective. Light infantry reinforced by engineer squad and equipped with SMET should be able 
to march 20 miles in five hours. Although an SMET does not offer the speed or protection of a manned vehicle, these unmanned systems should carry the soldiers' load, provide heavy firepower, conduct combat breaching, and clear routes. Soldier evaluations have shown that SMET can carry heavy loads across a wide variety of rough terrain: forest, desert, and jungle. System should carry $454 \mathrm{~kg}$ (1 000 pounds) of gear, including a radio and battery charger from a Stryker. The radio connected the squad, platoon, and company radios, as well as provided reach-back to higher command, artillery, and air support. The radio also gave all friendly forces a Blue Force Tracker position for every squad.

Some SMET vehicles were equipped with M2 heavy machine guns or M134 miniguns, mounted on Remote Weapon Stations (RWS). The dismounted Stryker infantry at Fort Bliss were not as positive about this capability as the 82nd Airborne scout platoon had been at Fort Benning. Much more work is needed on the dismounted operator interface. The durability and reliability of control system is not main problem. More important problem is limited actional and situational awareness during teleoperation. Another problem is stability - RWS dramatically increasing center of gravity and reduce possibility of operation in rough terrain.

The SMET systems were used by the combat engineers to assist in a variety of assault breaching techniques. They used for line clearance (about $0.6 \mathrm{~m}$ wide) from AP mine roller and AP mine flail. For field fortification they used loader and backhoe attachments. While the overall response was very positive, much more effort needs to be spent developing specific tools, tactics, and procedures to best utilize these new assets. The very small cube of an SMET, however, means that it may be the only tool available to combat engineers in the early stages of an expeditionary operation. Trials show that engineer attachment need a lot of hydraulic power and relatively high pulling forces. Moreover, for effective operation need much more higher lateral and longitudinal stability then transport application and takes much more space and reduce maneuverability of UGV.

Conducted test shows that small SMET vehicles cannot negotiate the terrain. These systems also did not carry enough payload to be worth the effort of operating. At the larger end of the scale, when systems approached the size of manned vehicles, there also were problems. An important advantage for dismounted infantry is being able to go where manned vehicles cannot. At Fort Bliss, larger SMET surrogates became high-centered in rough terrain and had to be towed off. At Fort Benning, the larger systems had difficulty with heavily wooded areas. The Hawaii jungle testing showed that larger systems are blocked by vegetation, while narrower vehicles can get through. Almost unanimously, the soldiers said that tracks were far superior to wheels in terrain.

Trials show that UGV were habitually overloaded. Soldiers don't care about weight of load. For this reason many SMET surrogates had great difficulty with overheating. Even the battery-powered systems had problems with electric motors overheating. Many mechanical components also proved too weak enough for the heavy loads that the soldiers put on the systems.

All vehicles had problems with stability on side slopes, although the narrower vehicles had a greater difficulty. All of the surrogate systems experienced problems with rollovers. The narrower SMET vehicles had more trouble with side slopes, but even the widest systems overturned. Dynamic stability is a notoriously difficult problem for remotely operated systems. Taking the operator out of the vehicle eliminates any vestibular and proprioceptive sense of the vehicle's stability. This difficult situation is compounded by operating the vehicles, at night, in rough terrain, using night vision goggles. Moreover, the power and torque needed to carry these loads across rough terrain is far greater than any traditional vehicle sizing of power-train would suggest. The rolling resistance of small and medium UGV is a few times higher than in traditional vehicle. The up-sized electric motors delivered the performance that the soldiers wanted, but under heavy loads in the hot desert environment, these motors overheated very quickly and then had to be shut down for about ten minutes to cool off.

During the trials, all of the SMET surrogate vehicles operated through simple wireless hand controllers, without using video. Trials show that typical SMET controller, with an $230 \mathrm{~g}$ hand controller and $1.8 \mathrm{~kg}$ radio repeater has a one kilometer range and 12 hour battery life. Adding video greatly increases weight and cost, while also reducing battery life. The Tactical Robot Controller (TRC) weighs about $10 \mathrm{~kg}$ and lasts for only a 2-3 hours.

Conducted tests of autonomy has shown that "follow me" systems are able to work successfully. But systems need to use for example three stereo pairs of thermal imagers, three stereo pairs of high resolution color video cameras, differential GPS, ultra-wide band radio triangulation, LIDAR, differential odometry, and an inertial measurement unit with a laser ring gyro and the system cost more than the base UGV.

The PACMAN-I (Pacific Manned-Unmanned Initiative, part of the Pacific Pathways exercises in 2016) in Hawaii, training event has been an next exercise to address the basis of issue for soldier multi-use equipment transport robots in the Pacific region. Robots didn't use regular Army radios as they do not provide the necessary bandwidth, they used a 4G LTE cellular phone network. The experiment also tested relays to boost signals so they could penetrate the thick foliage. Soldiers find that $[9,10,11]$ :

- they had, obviously, mobility challenges, more mobility challenges than they would ever expect in other terrain, a vehicle simply can’t climb, jump, or wade like a human soldier. Tanks overcome this 
problem by brute force, crushing obstacles or smashing them aside. A smaller tracked robot lacks the height and mass;

- tracked robots couldn't keep up with foot troops over rough terrain;

- there were numerous places, at least on this island, where that SMET cannot go;

- in a mission over rough ground, at a certain point, they're going to have to either abandon this machine or leave two people with it on guard;

- tracked robot with electric drive was most useful in cities and in an urban environment, where they can drive on flat surfaces;

- remote-controlled UGV was a big burden on the small units like squad or platoon.

Experience gained during the test, trials and military exercises has shown that fulfilment all demands in short times is not possible. There are too many technological gaps and contradictions. For fast UGV introduction reconstruction of demand was needed. Therefore, for selecting the best UGV the new main purpose and concept of operation was defined as well as clear requirements for it. Finally, the demand was reduced $[12,13,14,15]$.

UGV should carry about 1,000 pounds worth of soldier equipment. This equates to lightening the load of nine soldiers across an infantry squad. Exemplary of load consist:

- $\quad$ nine ruck-sacks;

- $\quad$ six boxes of MREs (Meal, Ready-To-Eat - about $10 \mathrm{~kg}$ );

- four 201 water cans.

This is about the equivalent of what a long-range mission for a light Infantry unit would need to carry. For testing and evaluation purposes, the simulated combat load also includes fuel cans and ammo cans as well.

The Army wanted the robots to be able to travel $100 \mathrm{~km}$ (60 miles) off-road in 72 hours or less (over three days) and to provide a spare kilowatt hour of power while moving and at least 3 kilowatt hours while stationary, silent operation should be possible and cost about $\$ 100,000$ or less.

There are no demands on armament, combat engineer equipment and attachment, advanced tele-operation system with cameras, no "follow-me" function, no autonomously navigation, no extreme obstacle negotiation possibility. The UGV should only have open architecture and possibility to introduce new control system later.

On the basis of redefined requirements, the new trials were conducted in 2017 at Fort Benning. The 17 UGV was involved in tests and four was selected for further evaluation $[15,16]$. It was:

- $\quad$ MUTT (wheeled, 8x8) - General Dynamic Land System;

- Hunter WOLF (tweels, 6x6)- HDT Global;

- Grizzly (rubber tracks) - Howe and Howe;

- $\quad$ MRZR-X (wheeled, 4x4)- Team Polaris.

All was hybrid because of silent drive demand. After one-year trials on 4 previously selected UGVs, the best solution was funded and contract for delivery of 624 UGVs was awarded [17]. It was MUTT 8x8.

It should be noted that selected UGV is not multi-purpose high or extreme mobility platform. It possesses wheeled undercarriage with rigid suspension - it means that UGV has limited possibility to develop high speed in rough terrain and in obstacle negotiation. It works well only on relatively smooth surface of cross-country and on soft low bearing capacity terrain, and on cross country roads. The width of vehicle is relatively wide and for this reason not fit to narrow path in the mountain or thick forest or jungle. But in the other hand low situated center of gravity with wide wheel track and rigid suspension gives vehicle with high lateral and longitudinal stability. The cargo deck is relatively low situated, completely flat with good dimension and easily accessible from each side. It can be easy loaded and easy transport loads with different size and weight and could transport even up to 10 soldiers. It is very good transport means if the terrain was not very rough.

Initially SMET was predicted as a support for dismounted squad in rough terrain. Tests and operational need verify these assumptions. Selected solution is very useful transport means in relatively long distance on moderate hard terrain and do not possess any autonomy. It should be noted that actual requirements are much lower than previous, but it enable implement UGV and support dismounted operation.

\section{Conclusions}

The present level of technology allows introducing in service UGVs able to efficiency support of dismounted operations. But it demands to work-out clear concept of operation and requirements which should corresponds to actual level of technology and possible UGV autonomy. Important role in this action should take analysis of terrain and planed activity. Special attention should be placed on demanded mobility level as a key feature, limited possibility of operation in terrain. Mountain, rocky or very soft terrain, thick forest or jungle and high number of drainage ditch in terrain can dramatically change the assessment of UGV. For demand evaluation can be used Analytic Hierarchy Process (AHP) or Quality Function Deployment (QFD) methods. 


\section{References}

1. Capability Vision. Reducing the Burden on the Dismounted Soldier, Center for Defence Enterprise Seminar 23 Apr 2009, Harwell, MOD 2009

2. Scott Fish. UGVs in future combat systems. Proceedings Volume 5422, Unmanned Ground Vehicle Technology VI. Defense and Security 2004, Orlando, Florida, United States (2004) https://doi.org/10.1117/12.537966

3. Andrew Feickert, Nathan Jacob Lucas. Army Future Combat System (FCS) "Spin-Outs" and Ground Combat Vehicle (GCV): Background and Issues for Congress, Congressional Research Service 7-5700 www.crs.gov RL32888 4. John Clements, Lindy Kirkland. Unmanned Ground Systems. AMCB UGV, 12 September 2011, https://info. publicintelligence.net/AMCB-UGVs.pdf, access 27.12.2019

5. Squad Mission Support System (SMSS), https:/www.army-technology.com/projects/squad-mission-supportsystem-smss/, access 27.12.2019

6. Northrop Grumman's CaMEL to Participate in Robotics Demonstration and Armed Live Fire, http://investor. northropgrumman.com/news-releases/news-release-details/northrop-grummans-camel-participate-roboticsdemonstration, access 27.12.2019

7. Squad Multipurpose Equipment Transporter (SMET) Tele-Operation Feedback System, https://www.sbir.gov/ node/1482293, access 27.12.2019

8. Kent Massey. Squad Mission Equipment Transport (SMET) - Lessons Learned for Industry. NDIA Ground Robotics Capability Conference, March 2, 2016

9. Sydney J. Freedberg Jr. Tiny Drones Win Over Army Grunts; Big Bots? Not So Much. August 08, 2016, https:// breakingdefense.com/2016/08/palmtop-drones-win-over-army-infantry-big-bots-not-so-much/ access 27.12.2019

10. Oriana Pawlyk. 'Mutt' Robot Stands Back at Big Marine Training Exercise, November 16, 2016, https://www. military.com/defensetech/2016/11/16/mutt-robot-marine-training access 27.12.2019

11. Tramel S. Garrett. Soldiers_test_robotics_on_battlefield. January 4, 2016, https://www.army.mil/article/160539/ soldiers_test_robotics_on_battlefield, access $2 \overline{7} .12 .2019$

12. Jon Harper. Army S\&T Efforts Focused on Robotics. 10/11/2017, https://www.nationaldefensemagazine.org/ articles/2017/10/11/army-s-t-efforts-focused-on-robotics, access 27.12.2019

13. Jon Harper. Robotic Vehicle Program Will Test Army's Acquisition Agility. 4/9/2018, https://www. nationaldefensemagazine.org/articles/2018/4/9/robotic-vehicle-program-will-test-armys-acquisition-agility, access 27.12.2019

14. Jen Judson. Four companies advance to build Army's equipment transport ground robot. December 14, 2017, https:/www.defensenews.com/land/2017/12/14/four-companies-advance-to-build-armys-equipment-transportground-robot/, access 27.12.2019

15. Jen Judson. Here's the robotic vehicle that will carry equipment for US troops. October 31, 2019, https:// www.defensenews.com/land/2019/10/31/heres-the-robotic-vehicle-that-will-carry-equipment-for-us-troops/access 27.12.2019

16. Angela Schubel, Erika Hanson. PEO CS\&CSS throws experimentation into the mix to speed acquisition. June 6, 2018, https://asc.army.mil/web/peo-cscss-throws-experimentation-into-the-mix-to-speed-acquisition/, access 27.12.2019

17. Kyle Mizokami. Meet the Army's New Robo-Mule, The SMET robotic vehicle is the answer to a soldier's prayers. Nov 1, 2019, https://www.popularmechanics.com/military/a29658123/army-robot-mule/, access 27.12.2019 18. https:/en.topwar.ru/66993-nazemnye-roboty-ot-zabrasyvaemyh-sistem-do-bezlyudnyh-transportnyh-kolonnchast-4.html

19. https:/en.topwar.ru/66993-nazemnye-roboty-ot-zabrasyvaemyh-sistem-do-bezlyudnyh-transportnyh-kolonnchast-4.html

20. http://www.howeandhowe.com/defense.html

21. https://www.defencetalk.com/us-army-selects-smss-autonomous-vehicle-for-afghanistan-deployment-36153/

22. https://commons.wikimedia.org/wiki/File:USMC_MUTT_vehicle_during_excercise_climbing.jpg

23. https://www.precisionremotes.com/vehicle-mounted-rows/general-dynamics-mutt/

24. https://blog.robotiq.com/whats-new-in-robotics-08.11.2019

25. https://www.armyrecognition.com/idex_2019_news_official_online_show_daily_partner/idex_2019_polaris displays_its_multi-mission_mrzr_x_vehicle.html

26. http://locomotionhorsnormes.e-monsite.com/pages/more-documentation-iv/116-6x6-wheeled-rigid-vehiclelight-4.html

27. http://defence.az/en/news/134779/grizzly-is-rugged-tank-robot-that-could-carry-soldier $\%$ E2\%80\%99s-stuff 